\title{
PLASTICIDADE REPRODUTIVA DO CARANGUEJO CHAMA-MARÉ LEPTUCA THAYERI (RATHBUN, 1900) (DECAPODA: OCYPODIDAE: GELASIMINAE): UMA ABORDAGEM LATITUDINAL
}

\author{
Guizardi, P.S. ${ }^{1,}$; Fortaleza, M.O. ${ }^{1}$ \& Bezerra, L.E.A. ${ }^{1}$ \\ ${ }^{1}$ Universidade Federal do Ceará (UFC), Instituto de Ciências do Mar, Laboratório de Zoobentos. \\ *Autor correspondente: polianasalve@gmail.com
}

Fêmeas ovígeras do caranguejo chama-maré Leptuca thayeri foram coletadas nos períodos chuvoso e seco nas regiões nordeste (Ceará) e sudeste (Espírito Santo) do Brasil, no ano de 2016. Análise de Variância dois fatores foi usada para testar as diferenças significativas $(p<0,05)$ no tamanho das fêmeas ovígeras, fecundidade relativa (número de ovos estágio I/Largura da carapaça), volume dos ovos e rendimento reprodutivo (RO) entre as regiões e as estações de cada local. Análise de Variância um fator foi aplicado para testar as diferenças significativas $(p<0,05)$ na mudança do número e volume de ovos durante a embriogênese. Fêmeas foram significativamente maiores no nordeste $(\mathrm{n}=49)(20,11 \pm 2,52 \mathrm{~mm}$; média \pm DP) (estação chuvosa $=19,73 \pm$ $2,50 \mathrm{~mm}$; estação seca $=20,89 \pm 2,46 \mathrm{~mm})$ do que as do sudeste $(\mathrm{n}=57)(17,96 \pm 2,15 \mathrm{~mm})$ (estação chuvosa $=18,58 \pm 1,44 \mathrm{~mm}$; estação seca =17,48 $\pm 2,49 \mathrm{~mm}$ ). Não houve diferença entre as estações, mas a interação local x estação foi significativa para a estação seca entre as duas regiões. A fecundidade média relativa variou significativamente entre as áreas e as estações, mas não apresentou significância na interação local x estação. No nordeste a fecundidade média relativa foi $711 \pm 251$ (estação chuvosa $=779 \pm 272$; estação seca $=597 \pm$ 161 ) e no sudeste foi $571 \pm 169$ (estação chuvosa $=613 \pm 151$; estação seca $=544 \pm 178$ ). O volume dos ovos no nordeste foi significativamente menor $\left(0,0070 \pm 0,0023 \mathrm{~mm}^{3}\right.$ ) (estação chuvosa =0,0074 $\pm 0,0025 \mathrm{~mm}^{3}$; estação seca $\left.=0,0064 \pm 0,0018 \mathrm{~mm}^{3}\right)$ do que no sudeste $\left(0,0097 \pm 0,0025 \mathrm{~mm}^{3}\right.$ ) (estação chuvosa $=0,0086 \pm$ $0,0019 \mathrm{~mm}^{3}$; estação seca $=0,0104 \pm 0,0026 \mathrm{~mm}^{3}$ ). Não houve diferença entre as estações, mas a interação local x estação mostrou ovos significativamente maiores na estação seca no sudeste. A perda e o aumento do volume dos ovos na embriogênese foram significativos nos dois locais estudados. O RO foi o mesmo nas duas localidades estudadas. Não houve diferença estatística significativa entre as estações e a interação local x estação foi significativa para RO das fêmeas na estação seca entre as duas regiões. O RO médio no nordeste foi de 0,083 \pm 0,031 (estação chuvosa $=0,092 \pm 0,027$; estação seca $=0,068 \pm 0,032$ ) e de 0,098 $\pm 0,036$ no sudeste (estação chuvosa $=$ de 0,081 $\pm 0,018$; estação seca $=0,108 \pm 0,041$ ). Os resultados demonstram uma plasticidade intraespecífica das características reprodutivas, onde a variabilidade observada pode estar relacionada às condições ambientais locais.

Palavras-chave: fecundidade, rendimento reprodutivo, sazonalidade, variabilidade intraespecífica, volume dos ovos. 